\title{
THE WEEDS OF TARANAKI
}

By G. R. MOSS, Department of Agriculture, New Plymouth

\section{SUMMARY}

THIS paper gives a brief historical background to the weed problems of Taranaki. The more important weeds are discussed as they occur in the following regions: waste places, dairy and fat lamb areas, the sandy coastal strip, and the store sheep lands.

Credit is given to the effectiveness of the modern chemical weedkillers, but it is stressed that they are not a substitute for good farm management practices.

\section{INTRODUCTION}

Of the major farming districts of New Zealand no district has had such a constant struggle to keep out weeds as Taranaki. Yet Taranaki is a highly productive province. Each year over a quarter of a million cows are milked and over a million sheep shorn on less than a million and a half acres. The history of farming in Taranaki is the history of the fight to control weeds.

Before European settlement the land was in heavy bush and coastal scrub. When the bush was cut difficulty was experienced in obtaining a clean burn because of the high rainfall. This added greatly to the trials of the pioneers, as poor forest burns meant masses of logs and stumps giving protection to second growth and weeds.

In these early stages of development many farmers became discouraged because of their inability to win the fight against the decline in fertility which led to deterioration of the pastures and invasion by weeds. Many sold their farms and shifted to other districts. The severity of the problem is reflected in a leader in the "Taranaki Herald" of 14 February 1910:

"With regret we learn that noxious weeds, especially blackberry [Rubus spp.] and ragwort [Senecio jacobaea] are rapidly gaining ground in some parts of the Province. ... There are some farms, we are told, which are becoming impenetrable thickets of blackberry, while the grazing capacity of others has been largely reduced on account of the spread of this and of ragwort. Farms which a few years ago carried a cow to 3 acres or less will not now graze one to less than 5 or 6 acres, and the milk supplies to the factory have been correspondingly reduced."

Restrictive legislation to help control weeds has been in force in Taranaki for over a century, but results have been disappointing. The weed problem has been aggravated by the soils and the climate.

With the exception of Eastern Taranaki, the soils are of volcanic origin. These volcanic ash soils are free draining, with a low natural fertility. Three hundred and ninety-one streams and rivers radiate out from the bush verges of Mount Egmont through these light soils and their banks are ideal places for weed growth

Normally the rainfall is evenly distributed throughout the year and the sunshine hours are high. In the coastal areas from Hawera to New Plymouth the average rainfall is between 45 and 60 in. On some farms higher up the mountain slopes, the rainfall is 120 in.

For simplicity, the weeds will be discussed under the following headings:

1. Weeds of waste places and bush verges

2. Weeds of the dairy and fat lamb areas

3 . Weeds of the sandy coastal strip

4. Weeds of store sheep lands

Naturally, many weeds occur in two or more of these areas so they will be discussed where they are most characteristic and any special points about their control and management in the other areas will be referred to in the appropriate section. 


\section{WEEDS OF WASTE PLACES AND BUSH VERGES}

There is no other province in New Zealand with such highly productive farming land that has so many waste areas as Taranaki. The 391 streams and rivers that flow from the Egmont National Park to the sea are only part of the picture. There are large acreages of native bush throughout the Province and the verges of this bush are often ungrazed and harbour weeds. Some bush areas are small and are kept for sentimental reasons.

Initially after a primary forest burn the secondary weed growth was of native species which included bracken fern (Pteridium acquilinum var. esculentum), wineberry (Aristotelia serrata), lacebark (Hoheria spp.) konini (Fuchsia excorticata), and tutu (Coriaria spp.) Today, after a secondary burn, we are liable to get such weeds as Australian fireweed (Erechtites atkinsoniae), blackberry, gorse (Ulex europaeus), inkweed (Phytolacca octandra), foxglove (Digitalis purpurea), and bracken fern. There is a considerable weed problem on the roadsides in the higher rainfall areas. A long term policy is necessary here to make allowance for moving the poles and drains back so that the verges can be levelled for mechanical cutting or stock grazing with the aid of an electric fence.

Most of the weeds of waste places have greater economic significance under extensive farming conditions and will be mentioned only briefly.

Australian fireweed is unpalatable to stock and is sometimes a problem after a burn when the level of fertility is low. It disappears with topdressing and pasture improvement.

Blackberry is a weed of low fertility and will not stand heavy stocking. It thrives under the high rainfall conditions at the foot of Mt. Egmont and is very susceptible to $2,4,5-\mathrm{T}$

Gorse eradication is difficult unless the area being sprayed can be adequately fenced for heavy stocking. On some of the intensively farmed areas gorse is removed from small waste gullies by filling them in with the aid of heavy machinery. The light soils of Taranaki make this job surprisingly easy. Heavily infested areas are often planted in trees.

Inkweed is one of the most abundant weeds in North Taranaki. It occurs in waste areas and appears in crops. It is also common in piggeries. It is a prolific seeder and the seed is spread by birds. Seedling control is satisfactory with 2,4-D, but adult plants are difficult to kill. A strong pasture and adequate stocking are necessary for control.

Barberry (Berberis vulgaris), like gorse, has spread from planted hedges and infestation is the result of lax grazing. As this is mainly a problem of the store sheep country, it will be dealt with more fully in that section.

Tutu is common on river banks and on roadsides. It is not a particularly serious problem and can be sprayed successfully, but because it is poisonous to stock strict control is necessary.

Bracken fern is palatable to stock during the spring and is therefore a problem only on unstocked and understocked areas. Most areas of Taranaki revert naturally to bracken fern if left unstocked.

Woolly nightshade (Solanum auriculatum) is an African plant originally grown as a garden ornamental. It is increasing in the district and some bad infestations can be found in North Taranaki.

Hemlock (Conium maculatum) is found scattered throughout Taranaki and appears particularly in waste places in populated areas. It is very poisonous and because of the danger to children more publicity is needed for its eradication. 
Giant dock (Polygonum sachalinense) is an eastern Asiatic weed which was probably introduced for horticultural purposes. It is not a serious weed yet, but appears to be spreading up the banks of the Waiwakaiho River. It has also been reported in the Ngaere district.

Lily of the valley vine (Salpichroa rhomboidea) is becoming a serious problem in Opunake township. It takes control in waste places, grows over hedges, and at Opunake is spreading into the golf links.

\section{WEEDS OF DAIRY AND FAT LAMB AREAS}

A. The intensively farmed lands generally speaking have different weed problems from the extensively farmed areas. On the dairy farms high fertility and open pastures leave the way clear for docks (Rumex spp.), giant buttercup (Ranunculus acris), and Californian thistle (Cirsium arvense), while on the sheep farms Californian thistles are the main problem. Both the dairy and the sheep areas have problems with crop weeds due to the high seed population in the soil.

Docks: There is a tendency today to sow high-producing open-type pasture species such as short-rotation ryegrass (Lolium multiflorum $\mathrm{x} L$. perenne), prairie grass (Bromus catharticus), and cocksfoot (Dactylis glomerata). These species under high fertility give an open sward and permit dock infestation. Control of mature docks by sprays is not satisfactory. Best results are obtained in this district from the use of the butyrics on seedling docks in new pastures.

Buttercups, especially giant and some bulbous (Ranunculus bulbosus), are becoming a problem on the damper areas. They are particularly bad in South Taranaki round Hawera and Mangatoki and round the Tariki-Norfolk districts of central Taranaki. Much publicity has been given to the invasion of these weeds over the last year.

Good results are obtained by spraying, provided a regular programme is maintained. Seed is spread largely through hay. Winter and spring management of an infested paddock is critical for control. Winter pugging with cattle and overgrazing under wet conditions open up the pasture and give ideal conditions for buttercup invasion. A thick pasture sward is essential for control. Where possible a mob of sheep assists on badly infested farms and can be used to clean up the buttercup during wet periods.

Thistles: Californian thistle is the only serious thistle weed in Taranaki. Nodding (Carduus nutans), variegated (Silybum marianum), and winged (Carduus tenuiflorus) thistles are present, but are being well controlled by farmers. Scotch thistle (Cirsium lanceolatum) is easily removed by spraying and is no problem on sprayable areas.

Californian thistle is one of Taranaki's worst weeds and is particularly serious in South Taranaki and in the Tikorangi district of North Taranaki. It is of interest to note that 60 years ago it was reported to be one of the principal weeds about New Plymouth. It is found growing under all conditions, but it occurs more particularly under the high fertility conditions of stock camps.

Control by spraying of the adult plant is not satisfactory. Results are variable. Spraying usually checks but seldom gives a complete kill. Most satisfactory results are obtained in new pastures by spraying the young plants with butyric weedkillers. Unfortunately many of the Californian thistle areas are unploughable.

Barley grass (Hordeum murinum) has increased over recent years. Stock yards have been a source of infestation and the position has been aggravated by several dry summers. Barley grass was recently declared a noxious weed by the Waimate West County. Control in the early stages while this weed is still confined to gateways and under trees is relatively simple with sprays, but unless positive action is taken it could become a serious weed especially on the coastal strip. It should never become the problem that it has on the east coast of the North Island because of our wetter climate. 
Crop weeds: On higher fertility lands with a history of cropping, such weeds as black nightshade (Solanum nigrum), inkweed, spurrey (Spergula arvensis), redshank (Polygonum persicaria) red root (Amaranthus hybridus formerly $A$. retroflexus), fumitory (Fumaria officinalis), and Californian thistle are problems. Areas such as Tikorangi, east of.Waitara, where cereal growing was at one time common, have very bad crop weed problems.

SMCA is giving reasonable results with brassica crops. Kerosene is still being used for weed control in carrots, but does not give consistent results. It is hoped that the new chemicals will overcome the carrot weed problem. It is unfortunate that new chemicals for weed control in crops are coming forward at a time when cropping in this district is on the decline.

B. The extensively farmed lands are covered with a multitude of weeds, but ragwort, gorse, and blackberry are the commonest and can be found in all districts round Mt. Egmont. Other weeds such as tall fescue (Festuca arundinacea), ratstail (Sporobulus capensis), rushes (Juncus spp.), and capeweed (Cryptostemma calendulacea) tend to be more dominant in certain districts.

Ragwort: At one stage in the early twenties it looked as if ragwort and blackberry would cripple the dairy industry. It was not until the late twenties that sodium chlorate was found suitable for its control and much credit must be given to this chemical. Today, ragwort can still be found on most farms, but it is a serious problem only on the developing lands, especially those with bush verges. Repeated chemical treatments, grazing by sheep, and good pasture management all play their part in control.

Gorse has been a weed in Taranaki for over a century. The Egmont County and the northern part of the Waimate West County are by far the worst areas for gorse. It is also a problem down the Waitara River valley and Mr F. R. L. Smith reports this infestation to have spread from an old deserted mission station below the Purangi bridge. Round New Plymouth river valleys and gullies are sources of infestation.

Gorse has become a major problem due to early plantings of hedges and lack of farming pressure brought about in many cases by unsatisfactory land tenure. Much of the coastal land where gorse gets out of control is leasehold land. The tenure position is a national problem, as much of this land is Maori land or Maori lease and is often abused by the lessee. I cannot see the gorse position getting any better in these districts. On the contrary, it could get worse.

Spraying gorse gives excellent control, but where there is a thick infestation it is useless unless good management practices such as fencing, oversowing, topdressing, and adequate stocking go hand in hand. Many of the gorse areas can be controlled with heavy machinery such as giant discs.

Blackberry is probably the most serious on the damper areas of the western part of the Waimate West County, but it is still a bad weed throughout Taranaki in areas difficult to farm, especially near Mt. Egmont. The final round in the fight to control blackberry has not yet been fought, but is well in hand.

The techniques of control are straight-forward, but mostly the limiting factor is finance. After the spraying comes perhaps bulldozing, cultivation, drainage, topdressing, fencing, and increased stocking. I should like to stress the necessity for topdressing, because a tight pasture sward and heavy grazing are essential to control blackberry.

Tall fescue is becoming a major problem on the coastal lands south-west of New Plymouth. It first becomes established on the roadsides, in pig paddocks and waste areas, and then gradually spreads into the pasture, especially in damp areas.

The most satisfactory control is obtained by thorough cultivation when taking two crops off an area, and then establishing a high producing pasture. If any tall fescue remains after this treatment spot spraying can be carried out. Chemical control with dalapon and amitrole is successful if repeated. 
A spring spraying, a summer burn followed by an autumn spraying, topdressing, and oversowing should give a large degree of control provided the area is adequately stocked. Unfortunately such methods are not economic over large areas. Waste areas of infestation can often be planted out with trees if other methods of control are not possible.

Tall fescue indicates lack of stock numbers, but unfortunately much of this country is undergoing development, and finance is a problem. Some farmers during the development stage are using the forage harvester to keep the tall fescue down. Results to date are proving satisfactory, especially if the crown of the plant can be removed during the winter months.

Ratstail is a problem on some of the steep sunny hill faces in North Taranaki, but it is not a problem on the well farmed areas.

Low rates of dalapon, down to $1 \mathrm{lb}$ per acre, applied in autumn give excellent kills. Ratstail is a symptom of low fertility and the removal of ratstail is of little use unless higher producing pasture species are sown and the fertility raised. Satisfactory control of ratstail is being obtained by regular feeding out of hay on bad patches or regular heavy topdressing with potassic phosphate manures.

Rushes: Though Taranaki is one of the wettest agricultural districts, rushes are not the problem they are on the stiff clay soils of other districts. They are more noticeable on the damper pockets and on the river flats north of Waitara and are the result of overstocking and wet conditions. Control is best by cultivation and drainage, if necessary. Spraying regrowth plants gives variable success.

Cape weed or Cape daisy is a prominent weed in the Alton-Hurleyville district south of Patea, and in the Waitara district. It shows up well in stock holding paddocks where overgrazing and low fertility prevail.

\section{THE COASTAL SANDY STRIP}

Because of erosion by the sea, the sand areas of Taranaki are not large. The more important areas are from New Plymouth to north of Waitara and from Hawera south.

Considerable variation in weed species is found due to differences in soil moisture and organic matter in the sands. Swampy areas and small lakes are common between the sea and the heavier soils. The main weeds of this region are lupins (Lupinus arboreus), sedges (Carex spp.), boxthorn (Lycium ferocissimum), blackberry, inkweed, fleabane (Erigeron canadensis), and fennel (Foeniculum vulgare). None of these weeds is difficult to remove, but methods vary according to circumstances.

Lupins are useful in sand conservation, but immediately the organic matter is such that pasture species will hold, they should be removed. Chemical control is effective, but may not be economic because of the low carrying capacity of such land. Cultivation is often not possible because of the danger of wind erosion to the sand. Mechanical control with choppers is effective, but only on workable areas. However, most farmers compromise and use all three methods in conjunction with good farming practices.

On the areas bordering the coastal strip grass weeds become a problem. Such weeds as tall fescue, ratstail, barley grass, paspalums (Paspalum spp.), kikuyu grass (Pennisetum clandestinum), and sedges are found. Very often this class of country is not being farmed intensively because of summer drought problems. Lack of stock, lack of fertility, and opening up of the grass sward in the summer all tend to aggravate these weeds. Chemical control of ratstail and barley grass is most effective, but the economics and success of chemical control of the other species are doubtful except under special circumstances. In general, they are best treated by other methods.

\section{WEEDS OF THE STORE SHEEP LANDS}

Inland from the dairying and fat lamb areas we find the steeper rugged papa sandstone back country. Its problems are stability and fertility. Much 
of this back country is still in bush and scrub and the main weed is manuka.

Manuka (Leptospermum scoparium) is not considered a true weed by some people, but it is as much a weed of low fertility and understocking as blackberry in other parts of the district. Because it is one of the few weeds still having to be cut by hand, it is an expensive weed to eradicate from second-class country. The New Zealand Forest Service at Te Wera have for a number of years been carrying out trials with chemicals, but have not yet found the ideal economic material for control.

Kanuka (Leptospermum ericoides) is found more round creeks and up the Waitara River valley. It is easier to cut and control than manuka.

Barberry is a bad weed in the Inglewood County and Central Taranaki, especially round the Douglas-Tututawa area and Tangarakau. One block of land has over 2,000 acres of scattered barberry bushes. Control is often mechanical where this is possible. We know that the oil-soluble ester concentrates of 2,4,5-T in diesel fuel oil give satisfactory control to cut stumps, but the most common method still used today is to cut the bushes in summer and treat the shoots with sodium chlorate in spring.

Hard fern (Paesia scaberula) is a widespread weed of the hill country. Subdivision is often not intensive enough to allow control by the traditional method of burning, oversowing, and good pasture and stock management.

Bidi bidi or piri piri (Acaena spp.) is a problem only on untopdressed run-off country such as in the Whangamomona district.

Stock management is critical for these store sheep lands. This is perhaps some of the most difficult country in New Zealand to handle. A farmer must have considerable experience and financial backing to stop pasture reversion and control weed infestation. Uncontrolled grazing promotes the growth of manuka or such weeds as ragwort. Without cattle, fern gets away. Without sheep, ragwort takes over.

\section{CONCLUSION}

We now have a selection of safe chemical weedkillers that will control the majority of our weeds; but these chemicals are not a substitute for good farm management practices. After eradication by treatment it is essential to consider the source of the infestation and the reason for it. Most of our weeds are present due to lack of farming pressure. This is brought about by insufficient stock, fertiliser, labour, capital, and incentive in some cases. Perhaps our land settlement policy is at fault. But it is not just a matter of politics. It is a matter of economics and population pressure. We have a great farming potential, and as our population grows and the farming pressure increases, our low-fertility weeds will diminish accordingly.

\section{Acknowledgments}

Assistance and advice was given by Messrs A. C. Burgess, R. F. L. Smith, and B. A. J. Smith. 